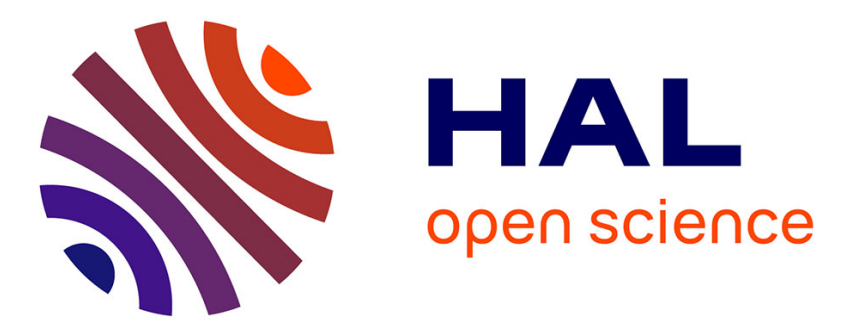

\title{
Chemorheology of Sol-gel Silica for Patterning High Aspect Ratio Structures by Nanoimprint
}

Alban Letailleur, Jérémie Teisseire, Nicolas Chemin, Etienne Barthel, Elin Sondergard

\section{- To cite this version:}

Alban Letailleur, Jérémie Teisseire, Nicolas Chemin, Etienne Barthel, Elin Sondergard. Chemorheology of Sol-gel Silica for Patterning High Aspect Ratio Structures by Nanoimprint. Chemistry of Materials, 2010, pp.10.1021/cm100285b. 10.1021/cm100285b . hal-00477545

\section{HAL Id: hal-00477545 \\ https://hal.science/hal-00477545}

Submitted on 29 Apr 2010

HAL is a multi-disciplinary open access archive for the deposit and dissemination of scientific research documents, whether they are published or not. The documents may come from teaching and research institutions in France or abroad, or from public or private research centers.
L'archive ouverte pluridisciplinaire HAL, est destinée au dépôt et à la diffusion de documents scientifiques de niveau recherche, publiés ou non, émanant des établissements d'enseignement et de recherche français ou étrangers, des laboratoires publics ou privés. 


\title{
Chemorheology of Sol-gel Silica for Patterning High
}

\section{Aspect Ratio Structures by Nanoimprint}

\author{
Alban Letailleur, ${ }^{\dagger, *}$ Jérémie Teisseire, ${ }^{\dagger}$ Nicolas Chemin,${ }^{\ddagger}$ Etienne Barthel, ${ }^{\dagger}$ Elin Søndergård ${ }^{\dagger}$ \\ ${ }^{\dagger}$ Laboratoire Surface du Verre et Interfaces, Unité CNRS/Saint-Gobain, 39 quai Lucien Lefranc, 93303 \\ Aubervilliers Cedex, France, ${ }^{\star}$ Service Produits Composites et Revêtements de Surfaces, Saint-Gobain \\ Recherche, 39 quai Lucien Lefranc, BP 135, 93303 Aubervilliers, France
}

alban.letailleur@saint-gobain.com

RECEIVED DATE (to be automatically inserted after your manuscript is accepted if required according to the journal that you are submitting your paper to)

To whom correspondence should be addressed Email: etienne.barthel@saint-gobain.com. Tel: +33 148 3955 57. Fax: +33148395562.

${ }^{\dagger}$ Unité CNRS/Saint-Gobain

Saint-Gobain Recherche

Among the existing methods, Nanoimprint Lithography (NIL) emerges as a simple route for surface patterning at the sub-micrometer scale over large areas. Thanks to their tunable properties, sol-gel materials form an alternative class of resist for NIL. However, there is only little understanding of the rheological properties responsible for their good imprint ability. Based on previous works on thermal curing of thermosets, this paper establishes a framework which can be used to tune the imprint conditions and to apprehend the rheological properties of complex hybrids materials. Using a combination of Dynamic Mechanical Analysis (DMA) and scratch test, we were able to model the 
thermorheological behavior of Methyltriethoxysilane (MTES) gel films during isothermal treatments in a time-temperature-transformations (TTT) diagram. Infrared spectroscopy study of the gel demonstrates the existence, for the same elaboration chemistry, of a condensation threshold independent of the temperature above which the material vitrifies: this reveals the closed relation between the rheology and the chemical microstructure of the gel. We also discussed the strong influence of the elaboration chemistry on the initial microstructure and therefore on the vitrification.

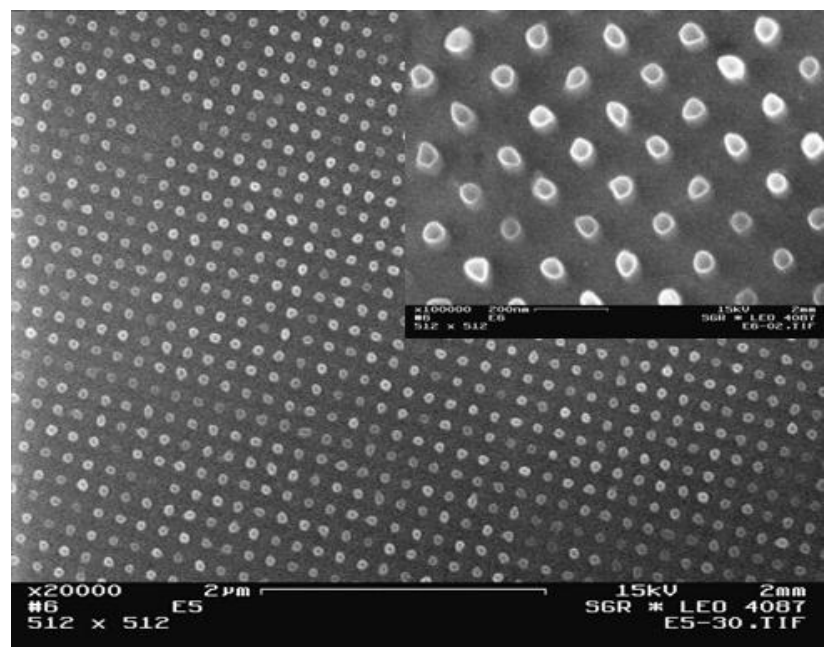

Figure 1. SEM picture of imprinted structures in MTES sol-gel coating: Dot array of about $50 \mathrm{~nm}$ diameter and $150 \mathrm{~nm}$ period and $150 \mathrm{~nm}$ height. The inset shows a detailed view. Imprints are performed at $130^{\circ} \mathrm{C}$.

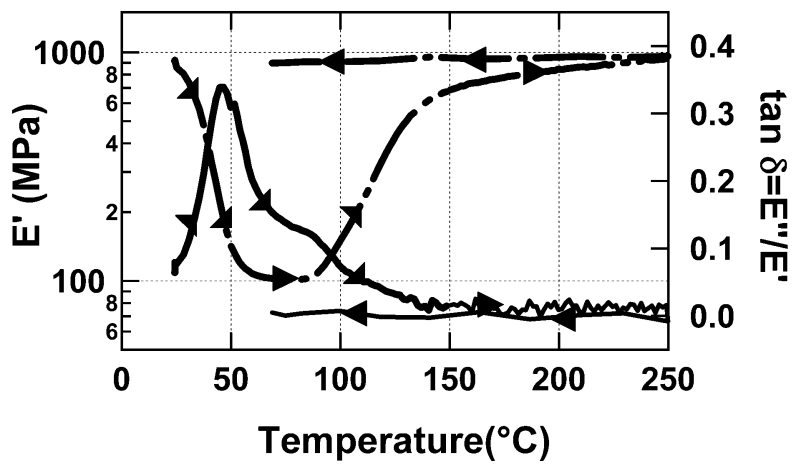

Figure 2. DMA Measurement on glass fiber mat impregnated with a MTES sol after $\mathrm{t}_{\mathrm{a}}=300$ minutes. Evolution of elastic moduli $(\cdot-)$ and dissipation $\tan \delta=E^{\prime \prime} / E^{\prime}(-)$ during a temperature cycle between room temperature and $250^{\circ} \mathrm{C}$ with $4^{\circ} \mathrm{C} \cdot \mathrm{min}^{-1}$ heating and cooling rates. 


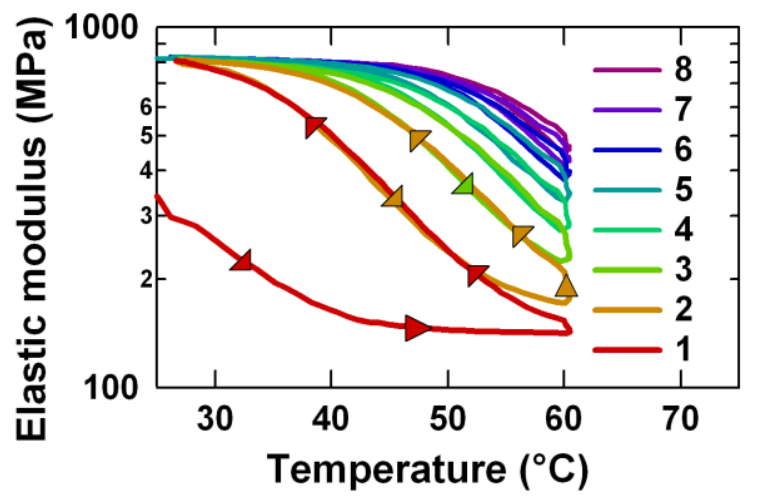

Figure 3. DMA Measurement on glass fiber mat impregnated with a MTES sol after $t_{a}=300$ minutes. Evolution of elastic modulus during eight consecutive temperature cycles between $25^{\circ} \mathrm{C}$ and $60^{\circ} \mathrm{C}$ with $4^{\circ} \mathrm{C} \cdot \mathrm{min}^{-1}$ heating and cooling rates with five minutes long plateau at the starting and ending temperatures.

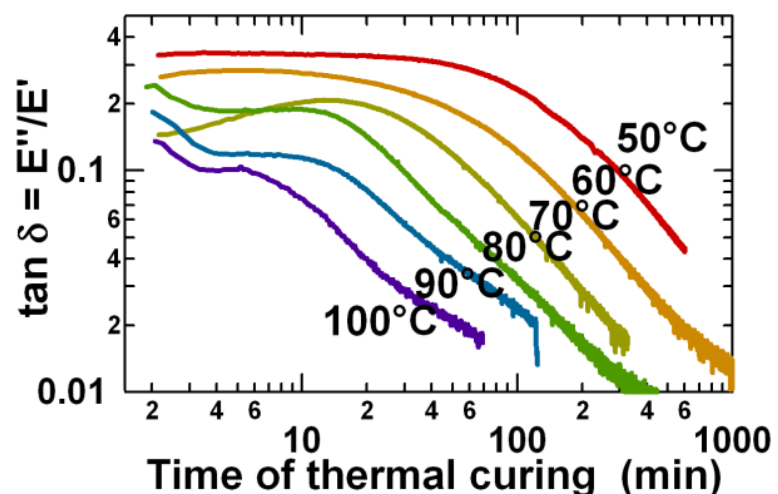

Figure 4. Isothermal DMA measurement on glass fiber mat impregnated with a MTES sol after $t_{a}=300$ minutes. Evolution of $\tan \delta$ during isothermal test after a $30^{\circ} \mathrm{C} / \mathrm{min}$ heating ramp (acquisition starts at the beginning of the isothermal plateau). 

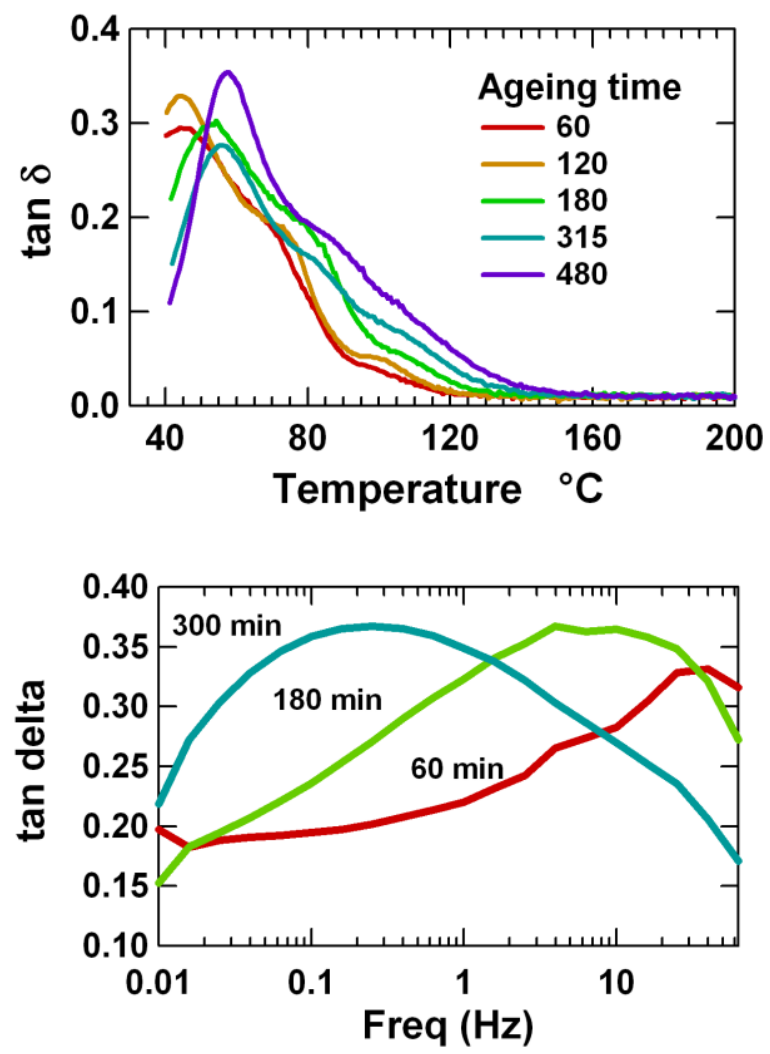

Figure 5. DMA Measurement on glass fiber mat impregnated with a MTES sol after $t_{a}=60,120,180$, 300 and 480 minutes. A) Evolution of the dissipation $\tan \delta=E^{\prime \prime} / E^{\prime}$ at $1 \mathrm{~Hz}$ during a temperature ramp. B) Frequency sweep between 0.01 and $80 \mathrm{~Hz}\left(5\right.$ points per decade) at $45^{\circ} \mathrm{C}$.
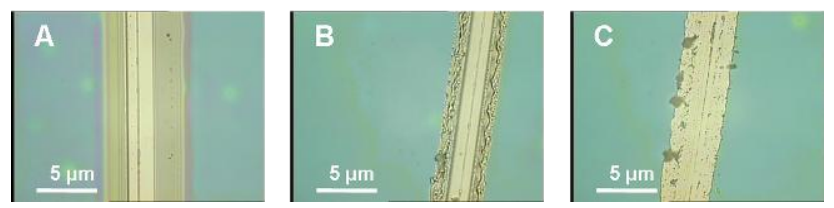

Figure 6. Optical microgramm of scratch morphology evolution during thermal treatment. At the beginning, parallel thickness fringes are observed (a: fluid), then whirls appear (b: viscous), and finally delamination of the layer occurs (c: brittle). 


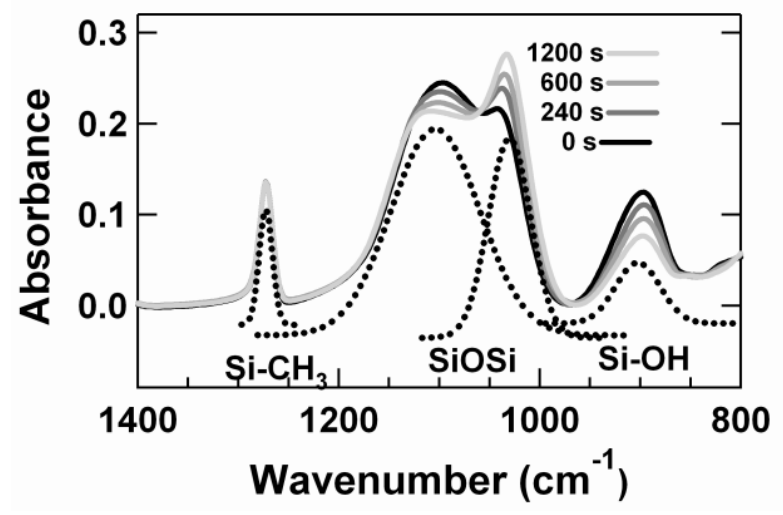

Figure 7. FTIR spectrum of a MTES layer deposited at $t_{a}=300$ min and after thermal treatment at $\mathrm{T}=95^{\circ} \mathrm{C}$ during $\mathrm{t}=0,4,10$ and $20 \mathrm{~min}$ (dark to light grey solid lines). SiOSi massif at $1100 \mathrm{~cm}^{-1}$ was separated in two peaks (dotted lines). All spectra are represented after baseline correction and normalization with respect to the $\mathrm{Si}-\mathrm{CH}_{3}$ peak area at $1230 \mathrm{~cm}^{-1}$.

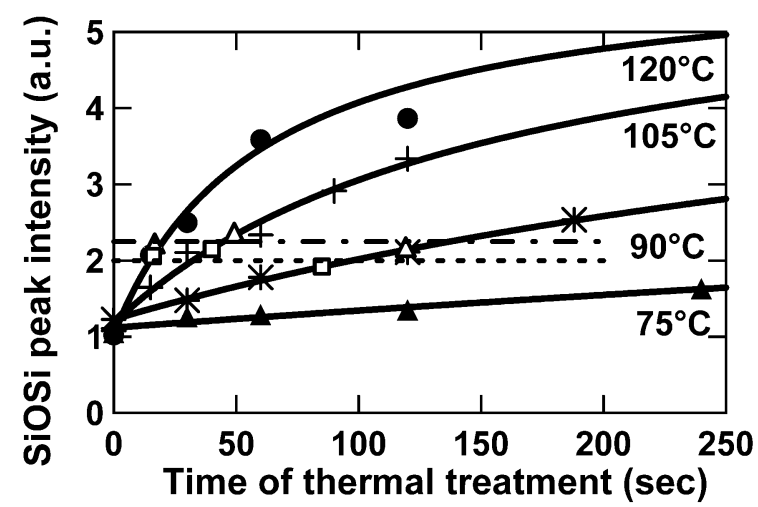

Figure 8. Evolution of the area of the SiOSi peak at $1030 \mathrm{~cm}^{-1}$ during thermal treatment at $\mathrm{T}=75(\mathbf{\Lambda})$, $90(*), 105(+)$ and $120^{\circ} \mathrm{C}(\bullet)$ (solid lines are obtained by fitting according to equation 3). The SiOSi peak area at the fluid-viscous ( $\square$, dotted line) and viscous-brittle ( $\Delta$, dashed and dotted line) transitions are also represented. Dotted lines are guide for the eyes. 


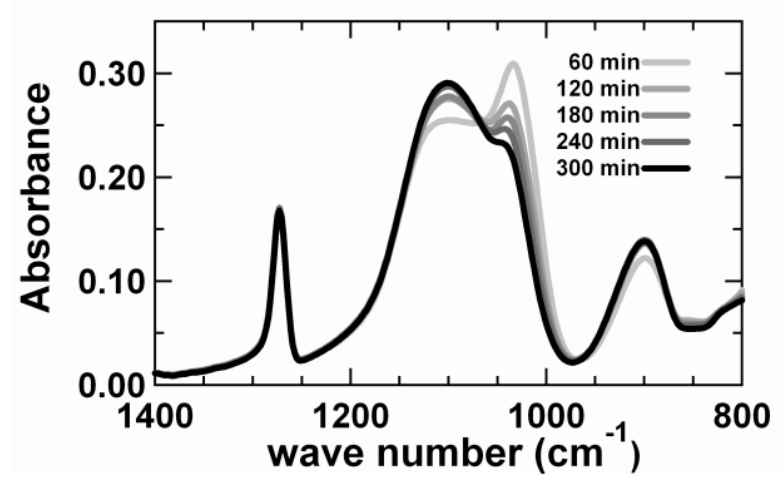

Figure 9. FTIR spectra of MTES gel layers deposited at $t_{a}=60,120,180,240$ and 300 minutes. All spectra are represented after baseline correction and normalization with respect to the $\mathrm{Si}-\mathrm{CH}_{3}$ peak area at $1230 \mathrm{~cm}^{-1}$.

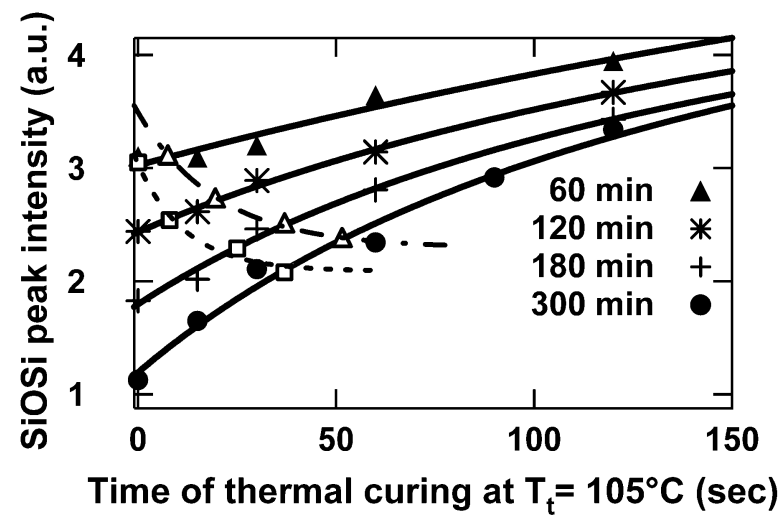

Figure 10. In FTIR experiments, evolution of the intensity of the SiOSi peak at $1030 \mathrm{~cm}^{-1}$ of sol-gel layers obtained after $\mathrm{t}_{\mathrm{a}}=60(\boldsymbol{\Delta}), 120(*), 240(+)$ and $390(\bullet)$ minutes during thermal treatment at $\mathrm{T}=$ $105^{\circ} \mathrm{C}$ (solid lines are obtained by fitting according to equation 3 ). The SiOSi peak area at the fluidviscous ( $\square$, dotted line) and viscous-brittle $(\Delta$, dashed and dotted line) transitions are also represented. Dotted lines are guide for the eyes.

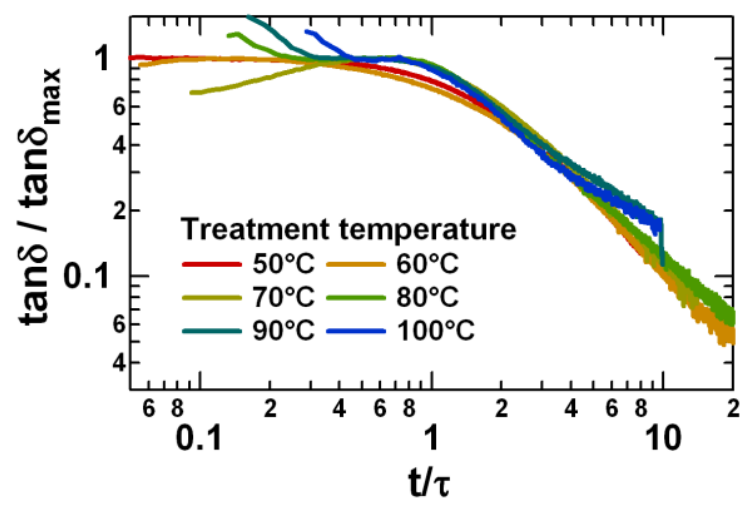


Figure 11. DMA Measurement on glass fiber mat impregnated with a MTES sol after $\mathrm{t}_{\mathrm{a}}=300$ minutes. Rescale of Fig. 4 into a master curve using $\tau=\mathrm{t} / \mathrm{t}_{\mathrm{DMA}}$ and $\tan \delta / \tan \delta_{\max }$ given in Table 2.

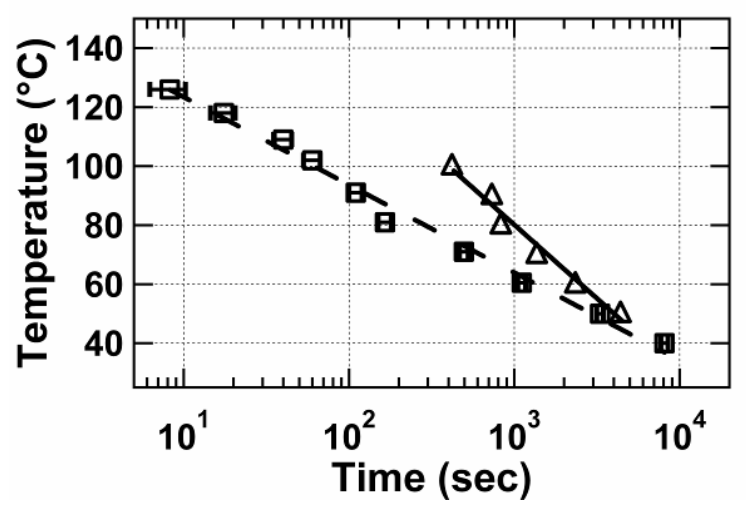

Figure 12. viscous-brittle transition time $t_{2}$ during the scratch test ( $\square$, obtained from Table 1) and the characteristic times of the DMA experiments ( $\Delta$ obtained from Table 2$)$. Exponential fitting curves are also represented (dashed line for scratch test and solid line for DMA).

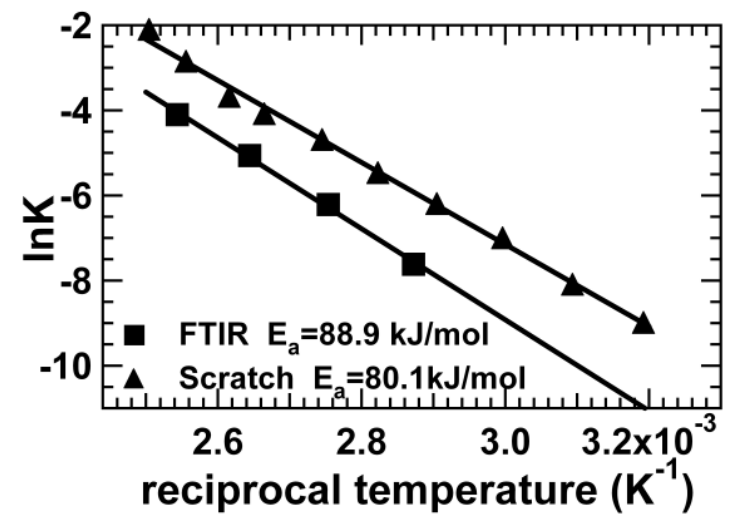

Figure 13. Arrhenius plot for the condensation reaction. The logarithm of the kinetics constants obtained by FTIR ( $\boldsymbol{\square})$ and from scratch test $(\boldsymbol{\Delta})$ are plotted as function of the reciprocal temperature. Linear fits are also represented for each experiment. 

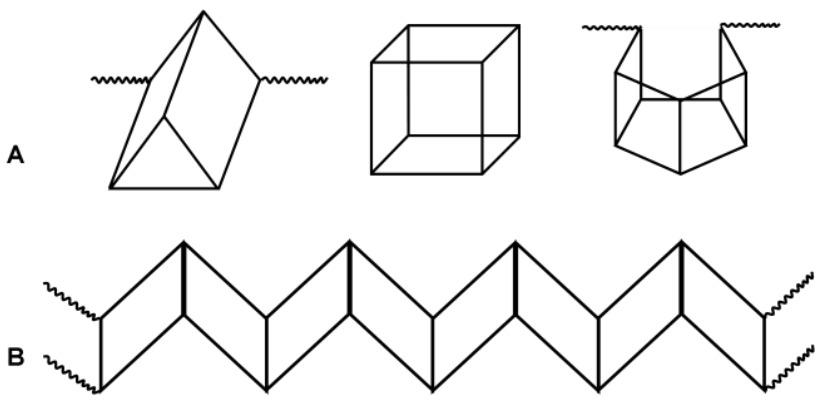

Scheme 1. Schematic view of (A) T-cube and (b) ladder-like SiOSi species. Silicon atoms are placed at the corners of the structures whereas oxygen atoms are in the middle of the lines. Wavy lines represent pending $\mathrm{SiOH}$ bonds.

\begin{tabular}{|l|l|l|l|l|l|l|l|l|l|l|}
\hline Temperature $\left({ }^{\circ} \mathrm{C}\right)$ & 125 & 118 & 110 & 100 & 90 & 80 & 70 & 60 & 50 & 40 \\
\hline $\mathrm{t}_{1}(\mathrm{~s})$ & $<5$ & 16 & 25 & 40 & 85 & 215 & 420 & & & \\
\hline $\mathrm{t}_{2}(\mathrm{~s})$ & 8.2 & 17.5 & 40 & 60 & 110 & 240 & 495 & 1110 & 3300 & 8100 \\
\hline
\end{tabular}

Table 1. In a scratch test, time needed to reach the fluid-viscous $\left(t_{1}\right.$ Fig. 6a-b) and viscous-brittle ( $t_{2}$ Fig. 6b-c) transitions as function of temperature for MTES layer prepared after $t_{a}=300 \mathrm{~min}$.

\begin{tabular}{|l|l|l|l|l|l|l|}
\hline Temperature $\left({ }^{\circ} \mathrm{C}\right)$ & 50 & 60 & 70 & 80 & 90 & 100 \\
\hline $\tan \delta_{\max }$ & 0.337 & 0.284 & 0.208 & 0.188 & 0.118 & 0.102 \\
\hline $\mathrm{t}_{\mathrm{DMA}}(\min )$ & $75^{\prime}$ & $40^{\prime}$ & $23^{\prime} 20$ & $14^{\prime} 10$ & $12^{\prime} 30$ & $7^{\prime} 10$ \\
\hline
\end{tabular}

Table 2. Parameters $\tan \delta_{\max }$ and $\mathrm{t}_{\mathrm{DMA}}$ used for the rescaling of Fig. 4 into a master curve (Fig. 11) as a function of temperature. $\tan \delta_{\max }$ is the value of $\tan \delta$ at the plateau. $\mathrm{t}_{\mathrm{DMA}}$ indicates the vitrification of the system and was measured by the intersection of the horizontal line at $\tan \delta_{\max }$ and the second line with a negative slope of the second regime (Fig. 4).

1 Chou, S. Y.; Krauss, P. R.; Renstrom, P. J Science, 1996, 272, 85.

2 Moran, I. W.; Briseno, A. L.; Loser, S.; Carter, K. R. Chem. Mater. 2008, 20, 4595.

3 Ngoumeni-Yappi, R.; Fasel, C.; Riedel, R.; Ischenko,V.; Pippel, E.; Woltersdorf, J.; Clade, J. Chem. Mater. 2008, 20, 3601. 
4 Fernández-Sánchez, C.; Cadarso, V.J.; Darder, M.; Domínguez, C.; Llobera, A. Chem. Mater. 2008, 20, 2662.

5 Ro, H.W.; Jones, R. L.; Peng, H.; Hines, D.R.; Lee, H. J.; Lin, E. K.; Karim, A.; Yoon, D. Y.; Gidley, D. W.; Soles, C. L. Adv. Mater. 2007, 19, 2919.

6 Peroz, C.; Heitz, C.; Goletto, V.; Bartel, E.; Sondergard, E. J. Vac. Sci. Tech B, 2007, 25 L27.

7 Brinker, C. J.; Scherer G. W. Sol-gel Science: The Physics and Chemistry of Sol-Gel Processing; Academic press: San Diego, CA, 1990.

8 Peroz, C.; Chauveau, V.; Barthel, E.; Sondergard, E. Advanced materials 2009, 21, 555.

9 Warlus, S.; Ponton, A.; Leslous, A. Eur. Phys. J. E 2003, 12, 275.

10 Sakka, S.; Tanaka, Y.; Kokubo, T. J. Non-Cryst. Solids 1986 82, 24.

11 Masai, H.; Takahashi, M.; Tokuda, Y.; Yoko, T. J. Mater. Res. 2005, 20, 1234.

12 Lebeau, B.; Maquet, J.; Sanchez, C.; Toussaere, E.; Hierleb, R.; Zyss, J. J. Mater. Chem. 1994, 4, 1855.

13 Enns, J. B.; Gillham, J. K. J. App. Polym. Sci. 1983, 28, 2567.

14 Innocenzi, P. J. Non-Cryst. Solids 2003, 316309.

15 Tejedor-Tejedor, M. I.; Paredes, L.; Anderson, M. A. Chem. Mater. 1998, 10, 3410.

16 Orel, B.; Ješe, R.; Vilčnik, A.; Lavrenčič Štangar, U. J. Sol-Gel Sci. Tech. 2005, 34, 251.

17 Brown, J. F.; Vogt, L. H.; Prescott, P. I. J. Am. Chem. Soc. 1964, $86,1120$.

18 Marcolli, M.; Lainé, P.; Bühler, R.; Calzaferri, G.; Tomkinson, J. J. Phys. Chem. B 1997, 101, 1171. 
19 Flory, P. J. Principles of polymer chemistry: Cornell University Press: Ithaca, NY, 1971.

20 Halley, P.; Mackay, M. Polym. Eng. Sci., 1996, 36, 593.

21 Sugahara, Y.; Okada, S.; Sato, S.; Kuroda, K.; Kato, C. J. Non-Cryst. Solids 1994 167, 21.

22 West, J. K.; Hench, L. L. J Mater. Sci. 1994, 29, 5808.

23 Núñez, L.; Taboada, J.; Fraga, F.; Núñez, M. R. J. of Appl. Polym. Sci. 1997, 66, 1377.

24 de Gennes, P. G.; Scaling Concepts in Polymer Physics: Cornell University Press: Ithaca, NY, 1979.

25 Van Assche, G.; Van Hemelrijck, A.; Rahier, H; Van Mele, B. Thermochimica Acta 1995, 268, 121; Rahier, H.; Van Mele, B.; Wastiels, J. J Mater. Sci. 1996, 31, 80.

26 Ko J. ; Park Y. ; Choe S. J. of Polym. Sci. Part.B: Polym. Phys. 1998, 36, 1981.

During the imprinting of a silica sol-gel thin film, a progressive shift of the glass transition temperature is observed and induces the vitrification of the materials. The subsequent strong modifications in rheology allows for large scale patterning with excellent spatial resolution and fidelity.

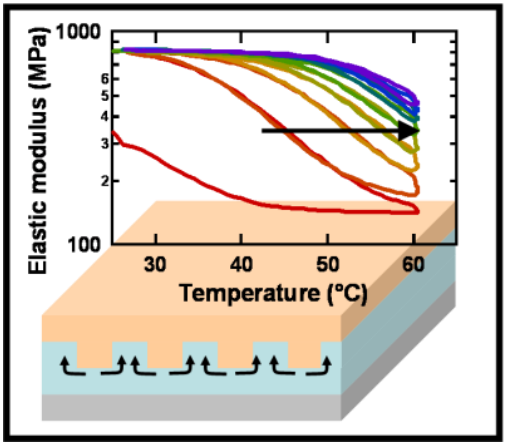

